
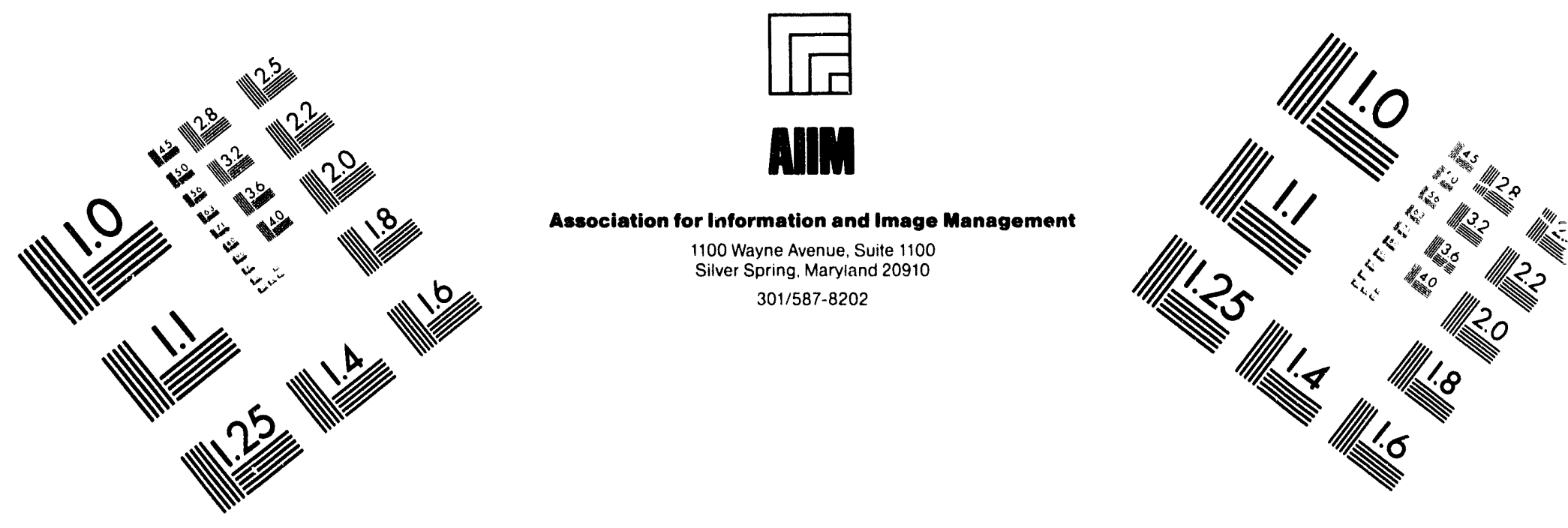

Centimeter

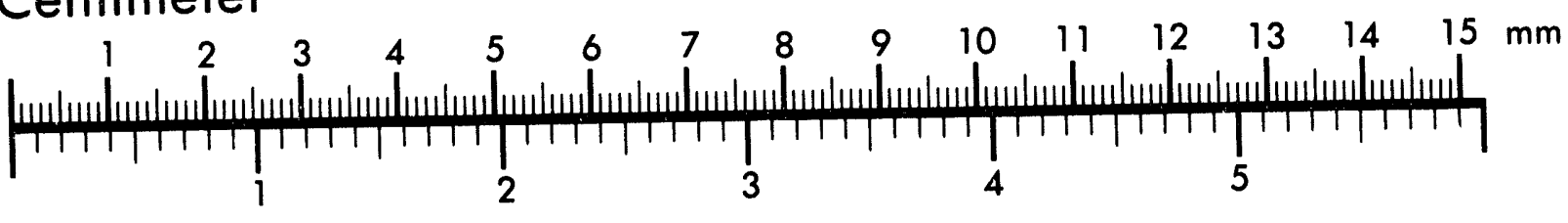
Inches
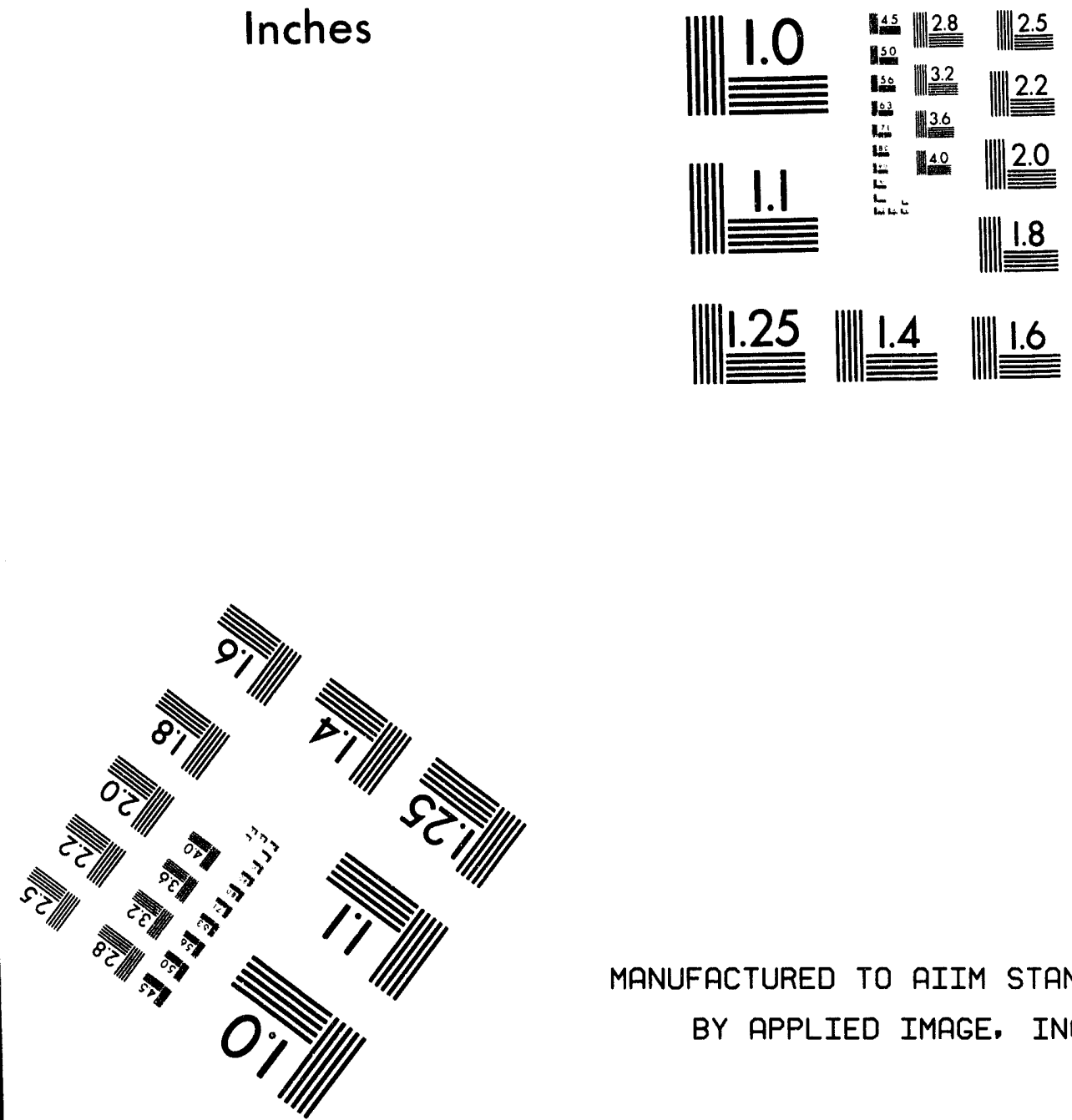

MANUFACTURED TO AIIM STANDARDS

BY APPLIED IMAGE, INC.

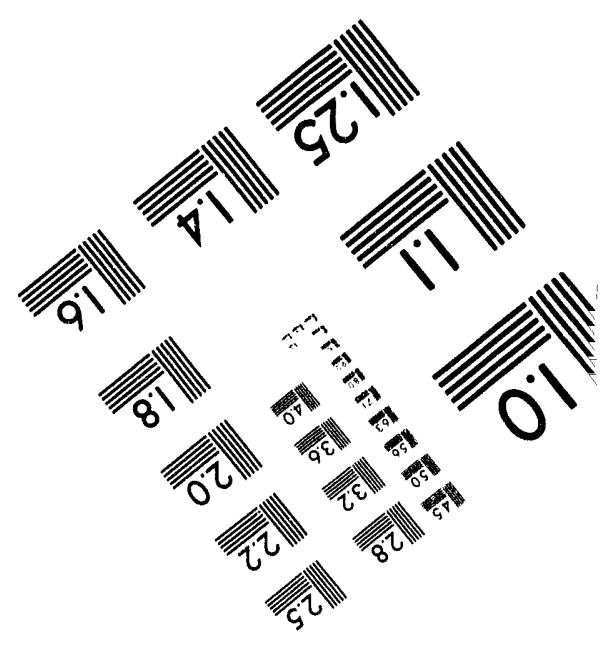



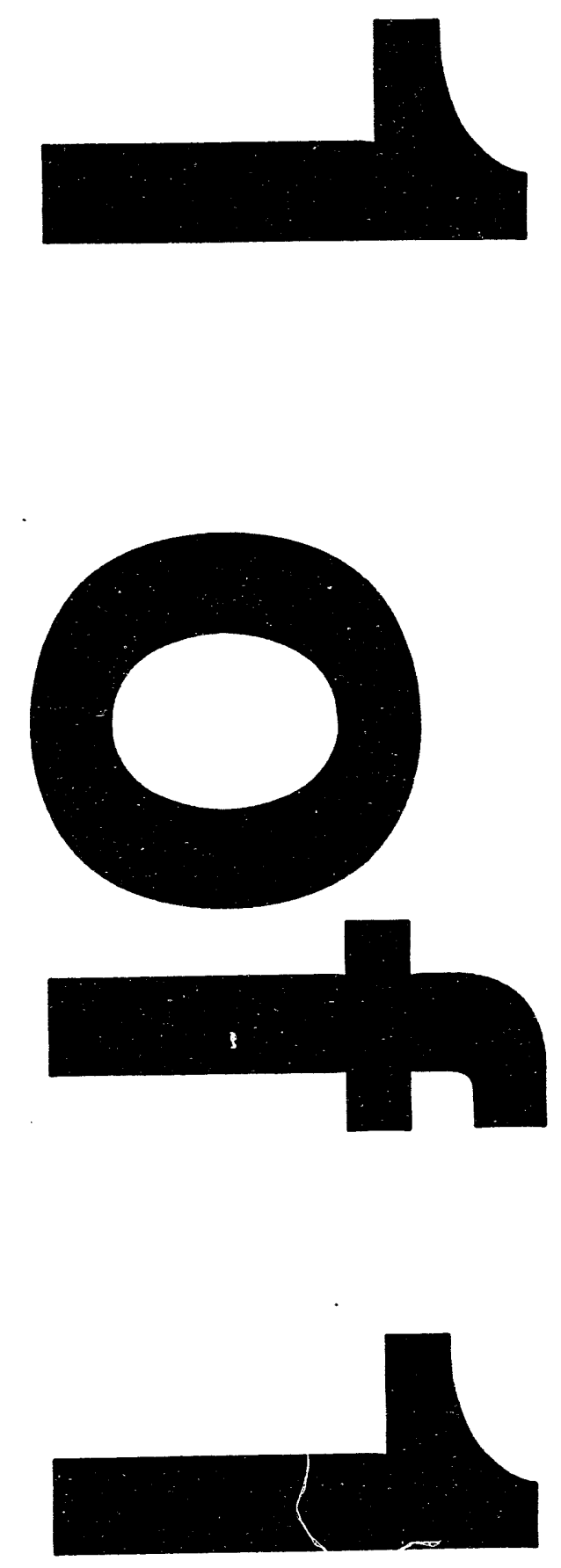


\section{Work Plan for Ground Water ELEVATION DATA RECORDER/MONITOR WELL INSTALLATION AT GUNNISON, COLORADO}

\section{August 1994}

\section{DISCLAIMER}

This report was prepared as an account of work sponsored by an agency of the United States Government. Neither the United States Government nor any agency thereof, nor any of their employees, makes any warranty, express or implied, or assumes any legal liability or responsibility for the accuracy, completeness, or usefulness of any information, apparatus, rroduct, or process disclosed, or represents that its use would not infringe privately owned rights. Reference herein to any specific commercial product, process, or service by trade name, trademark, manufacturer, or otherwise does not necessarily constitute or imply its endorsement, recommendation, or favoring by the United States Government or any agency thereof. The views and opinions of authors expressed herein do not necessarily state or reflect those of the United States Government or any agency thereof. 
This report has been reproduced frorn the best available copy.

Number of pages in this report: 21

For availability contact:

Office of Scientific and Technical Information

P.O. Box 62

Oak Ridge, TN 37831

(615) 576-8401 
WORK PLAN FOR GROUND WATER

ELEVATION DATA RECORDER/MONITOR WELL

INSTALLATION AT

GUNNISON, COLORADO

August 1994

Prepared for

U.S. Department of Energy

UMTRA Project Office

Albuquerque, New Mexico

Prepared by

Jacobs Engineering Group Inc.

Albuquerque, New Mexico 
TABLE OF CONTENTS

Section

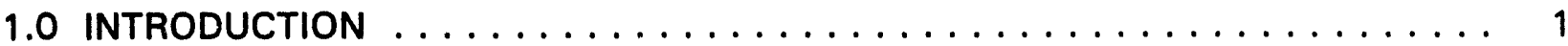

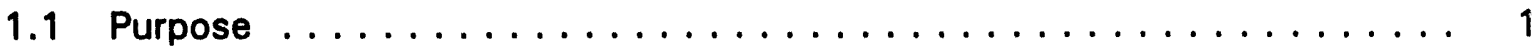

1.2 Data collection objectives $\ldots \ldots \ldots \ldots \ldots \ldots \ldots \ldots \ldots \ldots \ldots \ldots$

2.0 MONITOR WELL AND DATA LOGGER INSTALLATI NN TASKS $\ldots \ldots \ldots \ldots$

2.1 Monitor well and data logger locations . . . . . . . . . . . . . . 2

2.2 Permits, clearances, and access agreements . . . . . . . . . . . . 4

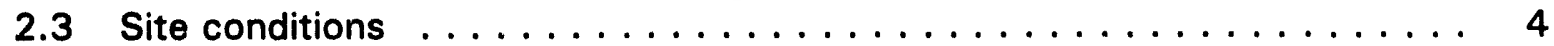

2.4 Well and data logger installation methods $\ldots \ldots \ldots \ldots \ldots \ldots \ldots \ldots \ldots$

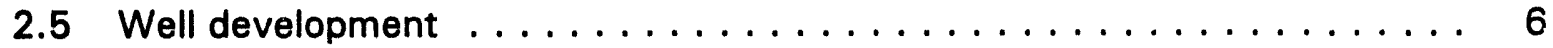

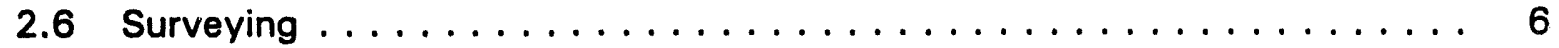

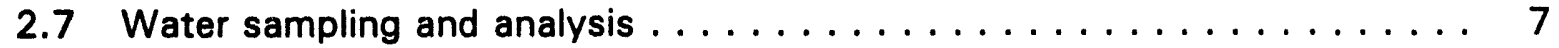

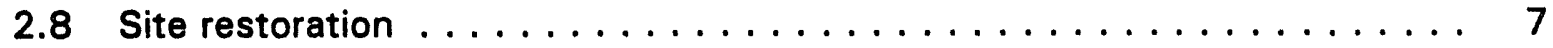

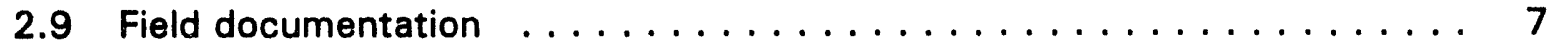

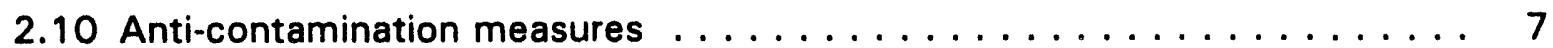

3.0 HEALTH AND SAFETY $\ldots \ldots \ldots \ldots \ldots \ldots \ldots \ldots \ldots \ldots \ldots$

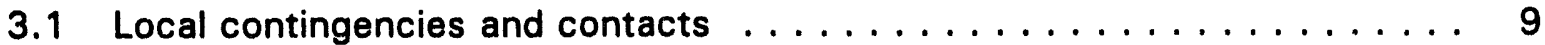

3.2 Health and safety audits . . . . . . . . . . . . . . . . . 9

4.0 WELL AND DATA LOGgER INSTALLATION TASK SCHEDULE $\ldots \ldots \ldots \ldots$

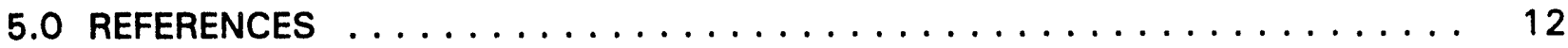




\section{LIST OF FIGURES}

\section{Figure}

Page

1 Proposed monitor viell and data logger location map in the processing site vicinity, Gunnison, Colorado ........................ 3

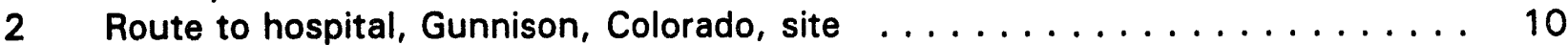




\section{LIST OF ACRONYMS AND ABBREVIATIONS}

$\begin{array}{ll}\text { Acronym } & \text { Definition } \\ \text { cm } & \text { centimeter } \\ \text { DCO } & \text { data collection objective } \\ \text { DOE } & \text { U.S. Department of Energy } \\ \text { FORE } & \text { field operation readiness evaluation } \\ \text { ft } & \text { foot } \\ \text { FTR } & \text { field technical representative } \\ \text { m } & \text { meter } \\ \text { PRS } & \text { project regulatory specialist } \\ \text { RAC } & \text { Remedial Action Contractor } \\ \text { SOP } & \text { standard operating procedure } \\ \text { TAC } & \text { Technical Assistance Contractor } \\ \text { UMTRA } & \text { Uranium Mill Tailings Remedial Action }\end{array}$




\subsection{INTRODUCTION}

\subsection{PURPOSE}

The purpose of this document is to describe the work that will be performed and the procedures that will be followed during installation of ground water monitor wells and ground water elevation data recorders (data loggers) at the Gunnison, Colorado, Uranium Mill Tailings Remedial Action (UMTRA) Project site. The monitor wells and data loggers will be used to gather required iime-dependent data to investigate the interaction between ground water and surface water in the area.

\subsection{DATA COLLECTION OBJECTIVES}

Data collection objectives (DCO) identify reasons for collecting data. The following are DCOs for the Gunnison ground water elevation data recorder/monitor well installation project:

- Long-term continuous ground water level data and periodic ground water samples will be collected to better understand the relationship between surface and ground water at the site.

- Water level and water quality data will eventually be used in future ground water modeling to more firmly establish numerical model boundary conditions in the vicinity of the Gunnison processing site.

- Modeling results will be used to demonstrate and document the potential remedial alternative of natural flushing. 


\subsection{MONITOR WELL AND DATA LOGGER INSTALLATION TASKS}

\subsection{MONITOR WELL AND DATA LOGGER LOCATIONS}

Seven shallow ground water monitor wells and 19 data loggers will be installed at the site. Data loggers will be installed in the 7 new monitor wells and the following 12 existing monitor wells (Figure 1): GUN-01-0013, GUN-01-0113, GUN-01-0145, GUN-01-0147, GUN-01-0160, GUN-01-0161, GUN-01-0181, GUN-01-0183, GUN-01-0188, GUN-01-0189, GUN-01-0196, and GUN-01-0197.

The proposed locations of the data loggers on existing wells and proposed monitor wells are discussed below and are shown in Figure 1.

Data loggers will be installed in existing monitor wells GUN-01-0013 and GUN-010113. Data from these wells will be used to monitor water level fluctuations at the processing site resulting from surface remediation construction activities.

One data logger will be installed in each of wells GUN-01-0145 and -0147 located along Tomichi Creek. The data loggers will provide continuous water level data to track potential hydrologic effects of seasonal dewatering at Valco, Inc., a cement plant. Ground water level data can also be correlated to surface water data acquired from the Tomichi Creek U.S. Geological Survey gauging station.

One data logger will be installed in each of wells GUN-01-0181 and -0183 located in the Dos Rios subdivision, over 500 feet ( $\mathrm{ft}$ ) (152 meters [m]) "inland" from the Gunnison River. Hydrographs have shown that upward and downward gradients have reversed occassionally by about $1 \mathrm{ft}(0.3 \mathrm{~m})$.

Two shallow monitor wells will be installed in the vicinity of well cluster GUN-010160 and -0161 -one as a stilling well adjacent to the Gunnison River (new well identification number GUN-01-0060), and the other next to the existing monitor well cluster (new well identification number GUN-01-0061). A data logger will be installed in each of these new wells and in the existing well cluster (GUN-01-0160 and -0161). Data from these wells will provide water quality and water level data at the confluence of the Gunnison River and Tomichi Creek.

Two shallow monitor wells will be installed in the vicinity of well cluster GUN-01-0196 and -0197-one as a stilling well adjacent to the west fork of the Gunnison River (new well identification number GUN-01-0096), and the other next to the existing well cluster (new well identification number GUN-01-0097). A data logger will be installed in each of these new wells and in the existing well cluster (GUN-01-0196 and -0197). These wells will provide water quality and water level data on the west side of the Gunnison River. Hydrographs have shown that there is a slight upward gradient of approximately $1 \mathrm{ft}(0.3 \mathrm{~m})$ between the deep (GUN-01-0197) and intermediate (GUN-01-0196) wells in the cluster. No information is currently available for shallow ground water levels in the vicinity. The proposed well GUN-01-0097 will provide information regarding the hydraulic 


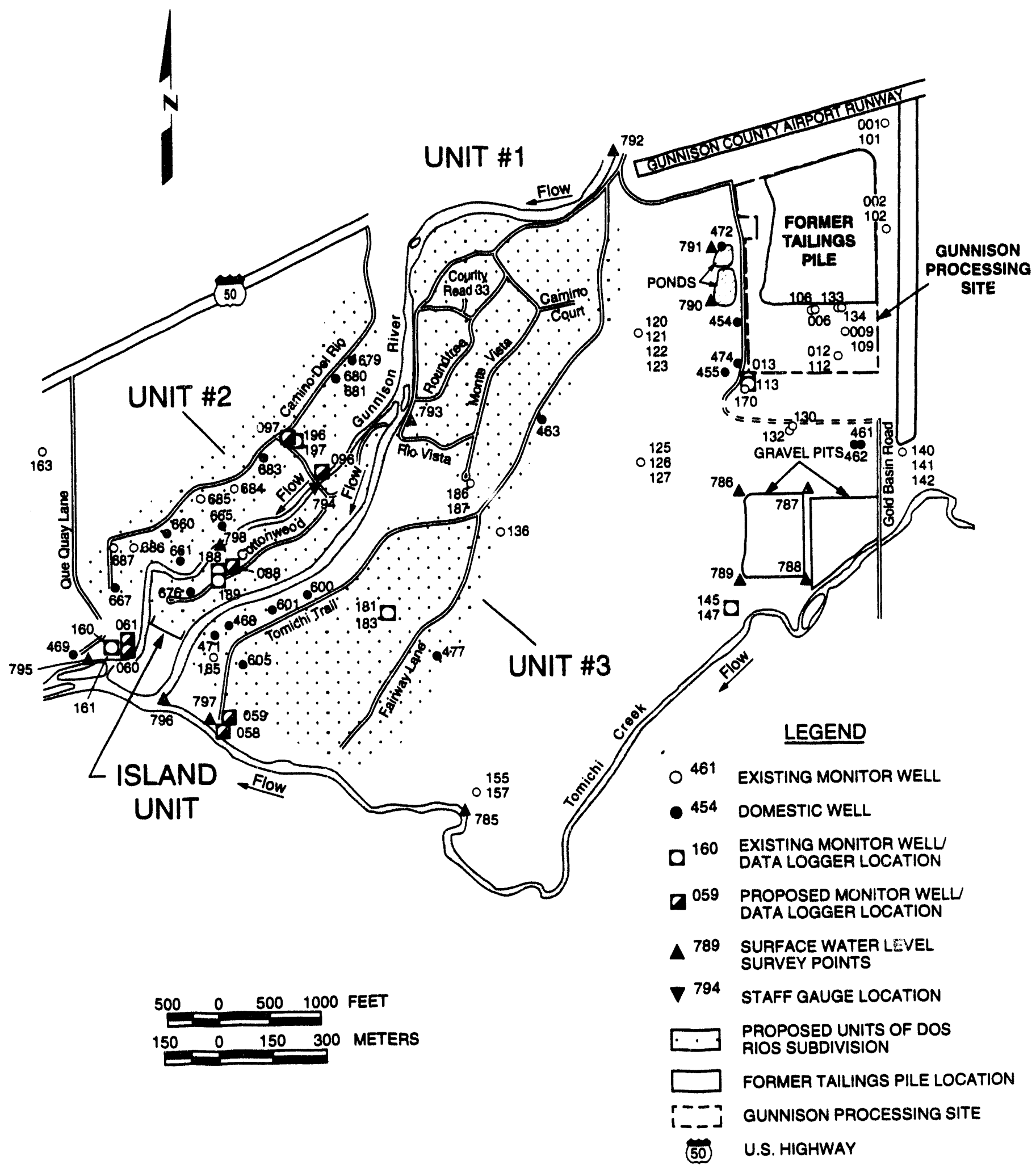

FIGURE 1

PROPOSED MONITOR WELL AND DATA LOGGER LOCATION MAP IN THE PROCESSING SITE VICINITY, GUNNISON, COLORADO 
connection (i.e., vertical gradient) between the shallow and intermediate screened intervals.

One shallow monitor well (new well identification number GUN-01-0088) will be installed to complete the existing well cluster GUN-01-0188 and -0189 . This well will provide shallow water quality data along Cottonwood Lane in the Island Unit of the Dos Rios subdivision. A data logger will be installed in each well in this monitor well cluster. Information gathered from these w'ells will provide a vertical profile of ground water relationships in wells screened in the shallow, intermediate, and deep portions of the alluvial aquifer on the island between the east and west branches of the Gunnison River.

Two shallow monitor wells will be installed at the south end of Tomichi Trail-one as a stilling well adjacent to Tomichi Creek (new well identification number GUN-01-0058) and the second approximately $100 \mathrm{ft}\left(30.5 \mathrm{~m}_{i}\right.$; northeast of Tornichi Creek (new well identification number GUN-01-0059). A data logger will be installed in each of these new wells to provide water quality and water level data along Tomichi Creek, upgradient of the confluence with the Gunnison River.

Existing monitor well GUN-01-0187 will be repaired. Water samplers reported an obstruction in the well at approximately $8 \mathrm{ft}(2.4 \mathrm{~m})$. A data logger will not be installed in this well, but the well is routinely sampled for water quality.

The data loggers will collect six water level measurements per day at 4-hour intervals. Field technicians will download the recorded data to a personal computer and check the data logger for proper operation at approximately 3-month intervals.

\subsection{PERMITS, CLEARANCES, AND ACCESS AGREEMENTS}

No monitor well permits or access agreements are needed for the installation of data loggers in existing wells. Property Management has verified that existing access agreements are sufficient to allow the installation of data loggers in existing monitor wells. Proposed monitor wells (Figure $1 /$ will require access agreements prior to field work. These new monitor wells will also require monitor well permits.

The Colorado Division of Water Resources will be contacted by the project regulatory specialist (PRS) for permitting information. The PRS will apply for and obtain any necessary permits. Property Management will obtain any needed access agreements before any field work is initiated.

\subsection{SITE CONDITIONS}

Based on field observations during regular ground water sampling, the depth to the water table at all proposed drilling locations is anticipated to be within $10 \mathrm{ft}(3 \mathrm{~m})$ of the land surface. Well logs from monitor wells close to the river show that the shallow alluvial aquifer materials consist of medium- to fine-grained, unconsolidated 
sand and gravel. A high percentage of cobbles and large boulders are present in the alluvial material.

Horizontal ground water flow is to the southwest. The alluvial aquifer is generally unconfined. However, noncontinuous layers of localized low hydraulic conductivity silt and clay may create semiconfined conditions with increasing depth in the alluvium.

\subsection{WELL AND DATA LOGGER INSTALLATION METHODS}

Because of the heterogeneous nature of the aquifer materials and the presence of cobbles and large boulders, the air rotary casing advance drilling method will be used to install monitor wells at the site. Monitor wells will be installed according to UMTRA Project standard operating procedure (SOP) 14.3.1 (JEG, n.d.). Each snallow well will be approximately $25 \mathrm{ft}(7.6 \mathrm{~m})$ deep and consist of approximately $5 \mathrm{ft}(2 \mathrm{~m})$ of 4-inch (10-centimeter [cm])-diameter PVC well screen and approximately 20 feet $(6 \mathrm{~m})$ of 4 -inch $(10 \mathrm{~cm})$-diameter PVC casing. Well construction materials and hand tools will be supplied by a licensed well driller contracted through Jacobs Engineering Group Inc., the Technical Assistance Contractor (TAC).

Data loggers and pressure transducers will be installed and calibrated in each monitor well following the manufacturer's instructions. Data loggers will be suspended in the monitor well for approximately 30 minutes to allow for cable stretch, water level equalization, and proper temperature equilibration between the ground water and data logger. Proper data logger operation will be verified by comparing the water level reading given by the data logger to the actual water level reading determined with a water level probe. Length of transducer cable will vary depending on depth to water and anticipated water level fluctuations in the monitor well. Existing ground water data, such as depth to water and historical water level fluctuations, will be reviewed to ensure data loggers and pressure transducers are installed so that the instruments operate properly throughout the year.

To verify proper data logger operation, data loggers will be checked after installation by field personnel. Approximately 2 weeks after installation, data logger operation will again be verified by field personnel. Once proper data logger operation is ensured, data will be downloaded at approximately 3 -month intervals.

In addition to the SOPs mentioned above, the following applicable SOPs (JEG, n.d.) will be followed during monitor well and data logger installation:

\subsubsection{Instructions for Field Technical Representative}

\subsubsection{Drilling and Test Pit Technical Representative}

14.1.4 Verification of Grout Mix for Monitor Wells

\subsubsection{FTR Daily Diary}


14.1.6 Procedures for Completing the Daily Field Activity Report

14.1.7 Field/Off-Site Procurement of Supplies \& Services

14.3.1 Drilling Procedures

14.4.1 Soil and Rock Core Borehole and Test Pit Logging

14.4.2 Preparation of Logs for UMTRA Project Documents

16.1.1 Monitor Well Installation

16.1.2 Well Development

16.1.19 Permitting Procedures for Installation or Decommissioning of Monitor Wells

16.1.22 Controlled Disposal of Potentially Contaminated Materials or Memorandum from Don Metzler to Clinton Smythe entitled "Evaluating Drill Cuttings and Well Development and Purge Waters"

\subsubsection{Location ID for Test Borings, Test Pits, and Monitoring Loctriors}

Internal communications will be maintained between the field representatives, site hydrogeologists, the TAC Contracts Department, Property Management, the site manager, and the U.S. Department of Energy (DOE). Before any installation of monitor wells or data loggers occurs, the Remedial Action Contractor (RAC) site manager will be notified of the upcoming activities, and the work party will check in with the RAC. Any problems or complications encountered during field work will be reported to the TAC site manager, who will forward the information to the DOE.

\subsection{WELL DEVELOPMENT}

No sooner than 48 hours after well completion, the well will be developed in accordance with UMTRA Project SOP 16.1.2 (JEG, n.d.) until the discharge is clear. The amount of water removed and approximate well yields will be recorded. The appropriate procedures will be followed to ensure proper disposal of development water.

\subsection{SURVEYING}

Once the monitor wells have been installed, they will be surveyed by a local surveying contractor to establish top-of-casing elevation and Colorado state plane coordinates. Surface elevations of nearby surface water bodies will be surveyed. Survey locations will include, but will not be limited to, upstream and downstream locations on the Gunnison River and Tomichi Creek, the campground pond, and Valco, Inc. gravel pits. One permanent staff gauge will be placed in the Gunnison 
River. The staff gauge will be attached to the small bridge crossing the river near existing wells GUN-01-0196 and -0197 . The river stage level on the staff gauge will be recorded at the time of surveying and every 3 months when data are downloaded from the data loggers. New monitor well top-of-casing, surface water bodies, and staff gauge elevations will be surveyed to the nearest $0.01 \mathrm{ft}(3$ millimeters).

\subsection{WATER SAMPLING AND ANALYSIS}

No water quality samples will be taken at this time, although the wells may be sampled in the future.

\subsection{SITE RESTORATION}

Moderate site disturbance is anticipated. However, areas of disturbed soil will be raked smooth by hand, all trash will be collected immediately, and established roadways and paths will be used whenever possible.

\subsection{FIELD DOCUMENTATION}

In addition to the daily diary kept by the field technical representative (FTR), the following documentation will be compiled and data collected:

- The monitor well locations will be photographed and located on a map. The elevations of the top-of-casing for each well point and the surface water elevations will be surveyed by the surveying subcontractor.

- Surface water elevation measuring points at the edge of the Gunnison River will be surveyed with respect to the top-of-casing of the nearest new monitor well.

- Water level measurements at each new well and from each existing monitor well will be recorded at least once just before the data loggers are set to begin logging in the wells.

- Proper functioning of the data loggers will be verified by recording the depth to water as reported by the data logger and a water level probe.

Copies of all pertinent field documentation will be maintained in the UMTRA Project Document Control Center.

\subsection{ANTI-CONTAMINATION MEASURES}

Before being taken onto the site, all well installation materials, including the drill rig, will be cleaned to the FTR's satisfaction as required. The TAC FTR will inspect equipment for the presence of hydraulic oil or grease, and, if necessary, the 
equipment will be steam cleaned to remove such material. The wells will be drilled in areas of lowest to highest ground water contamination to minimize rig decontamination. The drilling rig will be steam cleaned prior to moving to the next drilling location. 


\subsection{HEALTH AND SAFETY}

\subsection{LOCAL CONTINGENCIES AND CONTACTS}

All personnel involved with monitor well and data logger installation will have the foliowing equipment:

- Hard hat.

- Steel-toed boots.

- Safety glasses.

- Work gloves.

- Sunblock lotion.

- Fresh drinking water.

The following items will be on the site:

- First-aid kit.

- Fire extinguisher.

- Cellular telephone.

The location of the nearest hospital in case of emergency is Gunnison Valley Hospital (303-641-1456) located at 214 E. Denver Avenue, Gunnison, Colorado (Figure 2). The phone number for all emergencies is 911 .

\subsection{HEALTH AND SAFETY AUDITS}

The FTR will be responsible for observing that subcontractor personnel work activities are in compliance with UMTRA Project health and safety requirements and that Occupational Safety and Health Administration codes 29 CFR Parts 1910 and 1926 (1994) are followed during all phases of well installation. The applicable SOPs (JEG, n.d.) are as follows:

7.3.1 Occupational Safety and Health Complaints

7.3.2 Occupational Safety and Health Complaints for TAC Subcontractors

14.1.2 Instructions for Field Technical Representative 


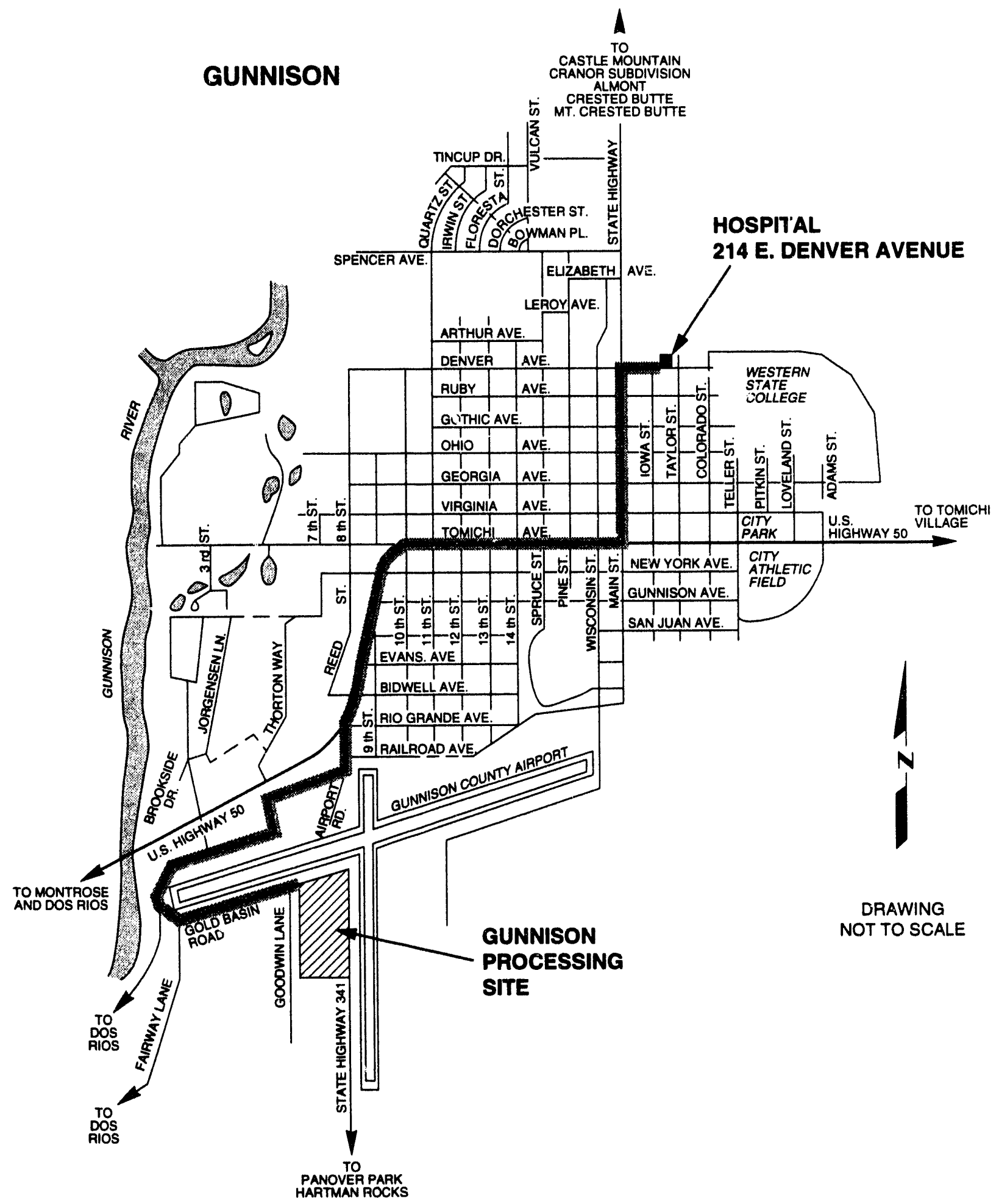

FIGURE 2

ROUTE TO HOSPITAL

GUNNISON, COLORADO, SITE 


\subsection{WELL AND DATA LOGGER INSTALLATION TASK SCHEDULE}

The activities discussed in this work plan are part of a larger e'fort to install new monitor wells and data loggers at the Gunnison, Rifle, and Grand Junction sites. The same drilling contractor will be used at all three Colorado sites. To minimize mobilization fees, the drilling contractor, upon completion of well installation procedures, will move directly to the next site. Drilling operations will start at the Gunnison site, then move to Rifle and finish at Grand Junction.

The tasks and accompanying tentative completion dates for this work plan are as follows:

Task

Award drilling subcontract

Conduct field operation readiness evaluation (FORE)

Procure equipment

Install wells

Survey wells and river

Install data loggers

Check data logger operation

\section{Completion}

August 21

August 31

September 16

September 17

October 6

October 9

November 2 


\subsection{REFERENCES}

JEG (Jacobs Engineering Group Inc.), n.d. Albuquerque Operations Manual, standard operating procedures, prepared by Jacobs Engineering Group Inc., Albuquerque, New Mexico, for the U.S. Department of Energy, UMTRA Project Office, Albuquerque Operations Office, Albuquerque, New Mexico.

\section{CODE OF FEDERAL REGULATIONS}

29 CFR Part 1910, Occupational Safety and Health Standards, Occupational Safety and Health Administration, Department of Labor (1994).

29 CFR Part 1926, Safety and Health Regulations for Construction, Occupational Safety and Health Administration, Department of Labor (1994). 

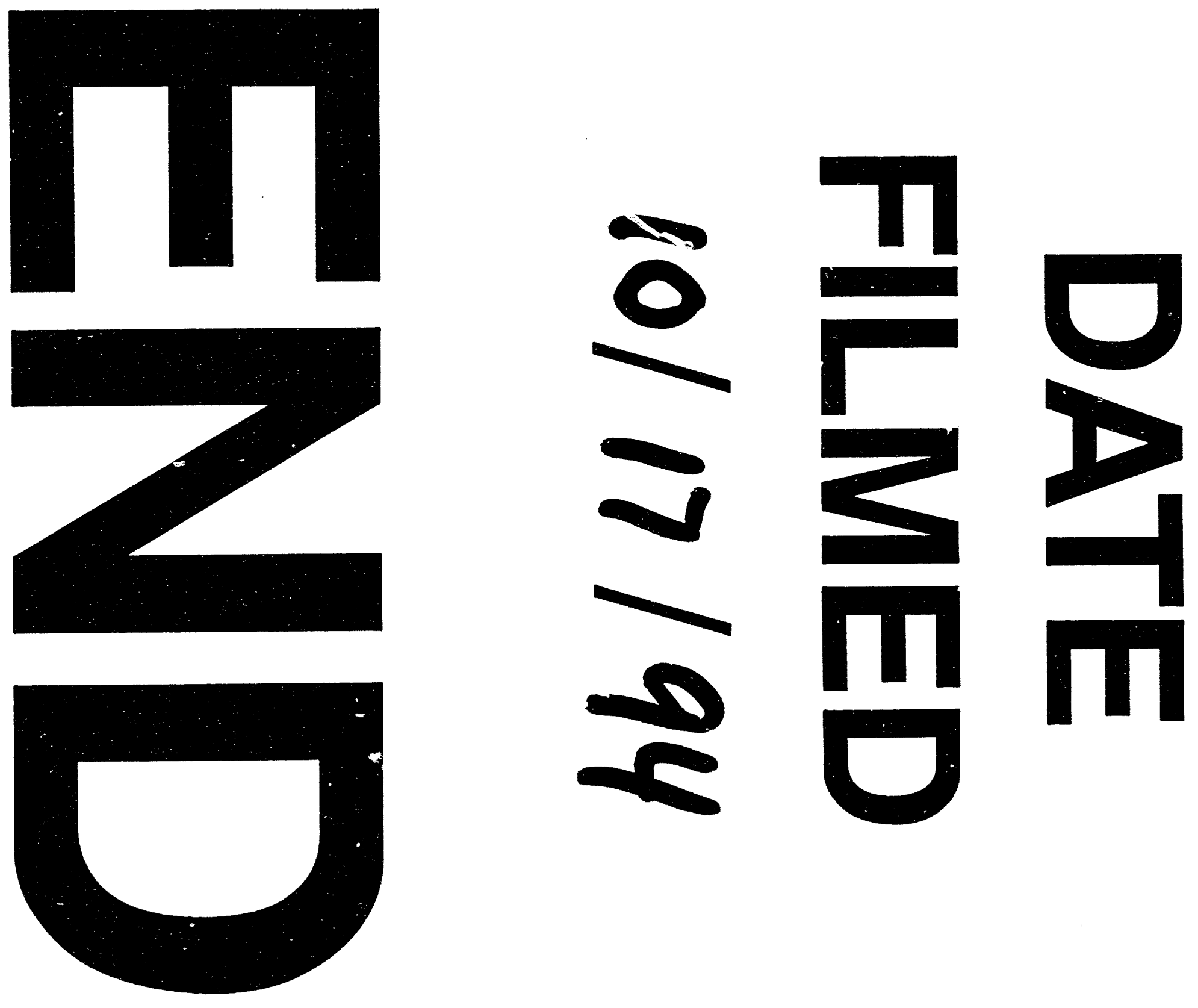
